\title{
Fuji Lining LC
}

National Cancer Institute

\section{Source}

National Cancer Institute. Fuji Lining LC. NCI Thesaurus. Code C89784.

A proprietary light-cured glass ionomer dental liner material. 